\title{
Instructor Adoption of E-learning Systems in Tanzania's Universities: A Proposed Multi-Factors Adoption Model (MFAM11)
}

\author{
Deogratius Mathew Lashayo ${ }^{\# *}$, Md Gapar Md Johar ${ }^{\#}$ \\ \# Faculty of Information Science and Engineering (FISE), Management \& Science University (MSU), Shah Alam, Malaysia \\ *Faculty of Computer Science, Information Systems and Mathematics (FCIM), Dar es salaam, Tanzania. \\ E-mail: mathew.deogratius@gmail.com,gapar@msu.edu.my
}

\begin{abstract}
Current studies show that there is no comprehensive adoption model in e-learning systems in universities. This problem opens up to too much debates about which models and frameworks fit well in an e-learning environment particularly in universities in Tanzania. This paper answers the two debatable questions, which are:(1) what are the factors that affect adoption of e-learning systems in Tanzania's universities, (2) what is the comprehensive e-learning adoption model in universities in Tanzania. This research study adapts DeLone and McLean (2003) IS model after an extensive literature reviews conducted in information systems and in e-learning systems. The findings from this research will add up to literature of limited factors' model and it will open it up for validation in a different universities' application domain.
\end{abstract}

Keywords - Adoption, e-learning systems, factors, models, frameworks, multi-factors, Tanzania, DeLone and McLean, universities.

\section{INTRODUCTION}

There is an increasing adoption of e-learning systems in universities in the world [1], [2]. Electronic learning system (here after e-learning system) is regarded as a form of teaching and learning in which a web-enabled learning environment is created which provide a smooth transfer of knowledge content between tutor and learner or learner and learner in which an Internet is acting as a medium of networking (wired or wireless) between communicating digital devises and learning sessions may be either synchronous or asynchronous [3]- [8]. In this context adoption of e-learning system means a phenomenon of acceptance and use of web-enabled e-learning system in education institutions for dissemination of learning contents [9], [10]. Perceived benefits of adopted e-learning systems in universities include saving time, saving cost, locationindependent (off-site) interactions, personalised learning styles, increased knowledge by an instructor provided with a webenabled system on which he/she can quickly construct the course contents, conducting any type of assessments, sharing a developed contents to peer instructor or learner, providing an immediate feedbacks and swift communication to both learner and instructor [11],[2].There are categories of e-learning systems used in learning institutions and universities in particular. These include Course Management Systems (CMS) of which Blackboard, WebCT, Moodle are good examples, then there is Learning Management Systems (LMS) of which
Netdimension EKP and Oracle ilearning are good examples, more ever there is Content Learning Management Systems (CLMS) of which Saba is a good example [12].

There is a concern about unmatched e-learning systems' adoption in universities in the Africa and developing countries with respect to the world. In the research conducted by Aparicio et al. in [13], it found that $65 \%$ of universities in the world have adopted e-learning systems. In African developing countries, the researches show that out 447 respondents from higher learning institutions, $52 \%$ of them have already adopted elearning systems [14] furthermore. In 2010, Unwin at al. in [15] reported that out of 358 respondents from 25 universities in the Africa, $49 \%$ of them have adopted e-learning systems. In subSaharan countries, Ssekakubo et al. in [16] reported that five (5) universities from four (4) different countries of sub-Sahara had e-learning already in place. Two (2) universities from the South Africa which are the Cape Town University and the Nelson Mandela Metropolitan University, one (1) university from Zambia i.e. the Zambia University, one (1) university in Kenya, i.e. the Nairobi University, one (1) university in Uganda, i.e. the Makerere University, were found using Moodle-based elearning systems. Therefore, the statistics show that Africa is lagging behind developing countries and developing countries is lagging behind the average global rate.

In Tanzania, current study shows that only $46 \%$ of both public and private owned universities have e-learning systems in place [17]. Munguatosha et al. in [18] documented that, 78\% 
of Higher Learning Institutions (HLIs) have a Moodle-based elearning systems. Lashayo and Gapar in [17] in a literature review study, show that $75 \%$ of all universities both public and private owned universities in Tanzania have Moodle-based elearning systems, therefore there are close results between universities and HLIs in terms of adoption of Moodle-based elearning systems. This mean that Moodle-based e-learning systems are in favour compared to other type of e-learning systems in both universities and HLIs in Tanzania. Furthermore, the $46 \%$ adoption implies that the Tanzania adoption rate is still way back.

An instructor is playing a key role in e-learning systems. Reference [18] reported that an instructor is a central to the adoption of e-learning system. He/she is acting as a facilitator and organiser of learning's course in this system. Course creation, course design and course delivery techniques they are all depend on an instructor [18]. Apart from course management and delivery, an instructor is providing academic interaction, interpersonal interaction and collaboration with other stakeholders in teaching and learning environment [19]. On top of that an instructor is also providing direct interaction, social interaction and organizational interaction [20], [21]. Therefore, an instructor key role cannot be underestimated in any e-learning systems in education institutions and particularly in universities in which the education paradigm is now shifting from information age to knowledge age [22], [23].

Apart from an increasing adoption of e-learning systems in universities in the world, there is a concern about how effective are the usage of e-learning systems by the universities' instructors. In Tanzania's universities, the University of Dar es Salaam (UDSM) is one of the forefront uptake of e-learning system [2]. In a total of 8,000 instructors of UDSM, only 767 are using it, in another Tanzanian's university, which is the Open University of Tanzania (OUT), in a total of 90 instructors, $87.6 \%$ have never used the system after being trained [24] while in Zimbabwe, in a total 66 instructors, $74 \%$ of them have never used it after attending training. Therefore, the perceived benefits expected from adoption would never be achieved unless the e-learnings are effectively used by instructors.

Current studies show that there is no comprehensive instructor's adoption model in e-learning systems specifically in universities in Tanzania, this open up to too much debates about which models and/or frameworks comprehensively affect successfully adoption of e-learning systems in the universities in Tanzania. This paper addresses this problem by proposing a Multi-Factors Adoption Model (MFAM11) because of limited number of factors of existing models and frameworks. References [25], [26], [1], [27] argued that limited factors significantly affect the adoption of e-learning systems in universities.

\section{LITERATURE REVIEW}

\section{A. Frameworks and Models.}

There are number of models and frameworks for technology adoption and implementation. Majority of them they are focusing on individual impacts. These include the Theory of Reasoned Action (TRA) authored by Fishbein and Ajzen [28], the Task Technology Fit model (TTF) authored by Goodhue and Thompson [29], The Technology Acceptance Model (TAM 1) authored by Davis [30], The technology acceptance model
(TAM 2) authored by Venkatesh and Davis [31] and the Unified Theory of Acceptance and Use of Technology (UTAUT) authored by Venkatesh, Morris, Davis, and Davis [6], however there other group of theories and models which are focusing on firm/organization these include: the Technology Organisation Environment (TOE) developed by Tornatzky and Fleischer [32], the Diffusion on Innovation (DOI) authored by Roger [33] and the DeLone and McLean (2003) authored by DeLone and McLean [34]. This research is interested in measuring the perceive benefits of an organization (universities) as an impacts factor of e-learning systems' adoption rather than impacts on individual immediate user. E-learning system is a typical Information System [35]. DeLone and McLean (2003) in [34] is the model developed purposely to measure an Information Systems (IS), therefore it is suitable to be a base model for this research study.

The DeLone and McLean (2003) in [34] IS model is used broadly in information systems adoption and implementation as well as in e-learning systems for the same course [36]. It is approximated that $38 \%$ of articles have used (referencing and extending) [34], [37], [26]. This model has passed through two steps of evolution which are: DeLone and McLean (1992) model and DeLone and McLean (2003) model. A total of 300 articles were used this model in the range of 1992 to 2003 [34]. In between 1992 to 2014 the total of 3500 articles have used these models [2]. This demonstrate how strong these models are, in information systems and e-learning systems and updated model in particular which is DeLone and McLean (2003).

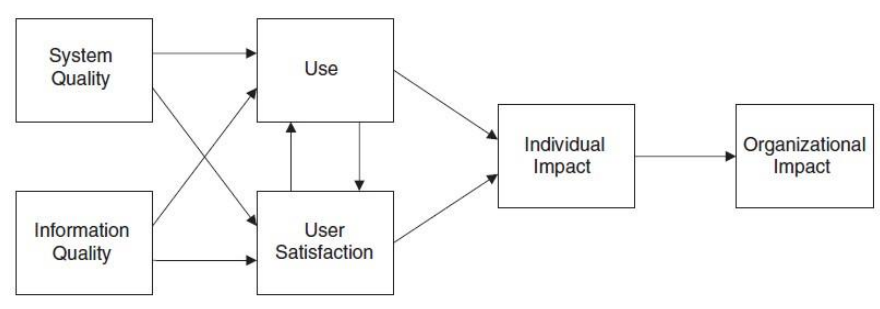

Fig. 1 The DeLone and McLean (1992) model. Reprinted from The DeLone and McLean Model of Information Systems Success [38].

The first model of DeLone and McLean (1992) in [38] was developed with six constructs based on idea of causal-impact analysis [38] as shown in figure 1.The two exogeneous design constructs which are System Quality and Information Quality are the causal for Use and User Satisfaction of an information system, and once the user will start using the system then an Individual impacts will start being realized and later on, an Organization impacts which lead to two consecutive constructs (Outcomes) which are Individual Impacts and Organizational Impacts. Ten years later, DeLone and McLean reviewed their first model of 1992 after recommendations from range of studies and resulted to the new model which is the DeLone and McLean (2003) model [34] in figure 2. The previous researches' findings on DeLone and McLean (1992) were shown that many organizations were in need of Information Technology (IT) service supports. This construct was added on DeLone and McLean (1992) [38] and termed as "Service Quality" and Intention to Use construct was added in 1992 model and fused together with Use, therefore a new construct was called "Intention to Use/Use" was formulated which will measure both attitude of user to use an information system and 
behavioural use. On top of that impacts are more on organization or group or community than on individual bases, therefore a new model was established which called the DeLone and McLean (2003) IS Success model [34] as shown in figure 2.

Despite the strength of DeLone and McLean (2003) model, but it is neither universal model nor comprehensive model as it still shown to have some weaknesses in some of the following areas: It has not considered the Social characteristics of systems, examples Trust of users and Social usefulness [39]. Also, it has not considered the culture and contextual aspect [22], Therefore, other researchers have extended the DeLone and McLean (2003) into different context in e-Learning systems. Those studies including [40], [41], [42], [26], [25], [2], [42], [1], [43].

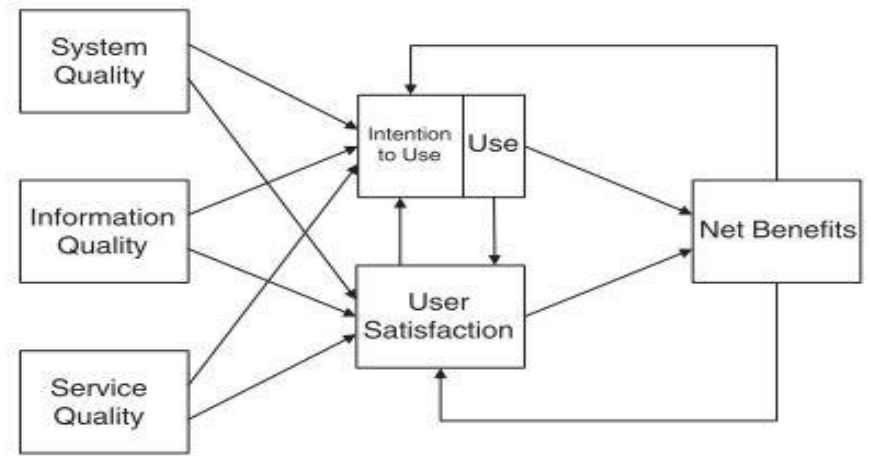

Fig. 2 The updated D \& M model. Reprinted from The DeLone and McLean Model of Information Systems Success: A Ten-Year Update [34].

The model which was proposed by Holsapple and Lee-Post in [40] with three main themes, System Design and Development which contained System Quality, Course Quality and Service Quality; System delivery which contain Use and last theme is System Outcome which contains Net Benefits and User Satisfaction, this model was validated in 2009 in university of Kentucky, using the action research methodology, the methodology used in this research limit extrapolation of its results to other universities. Ozkan and Koseler in [42] was tested a developed model called hexagonal e-learning assessment model (HELAM) in Turkey as preliminary study and in a sample of only 84 students of a single university called Brunel in United Kingdom (UK) in actual study and proved valid HELAM, this model has six (6) constructs but its limitation lies on single university results. Hassanzadeh et al. in [26] developed a model called MELLS with ten (10) constructs but this model was tested in sample of data from six (6) universities in Iran, [25] developed a model with eight (8) constructs and validated in USA in a single university only. Mtebe and Raisamo in [2] developed a model with six (6) constructs by adapting DeLone and McLean (2003) and validated it with a sample from 200 students in a single university in Tanzania which was University of Dar es Salaam (UDSM), same to Lwoga in [36] developed a model with seven (7) constructs and tested it in a sample of 272 students in a single university which is Muhimbili University of Health and Allied Science (MUHAS), Mohammadi in [1] developed a model by adapting DeLone and McLean (2003) model with nine (9) constructs and tested it in a sample of students from four (4) universities in Iran. Tossy in [43] used DeLone and McLean (1992) with nine (9) constructs and testing them in a sample of 306 students in Tanzania. None of these studies particularly in Tanzania had quantitatively researched on instructors' perceptions and the other were tested in other regions like Iran, USA, Australia, UK and Turkey.

There are still unprecedented adoption factors in universities in Tanzania e-learning systems [43]. Therefore, this research's proposed model called Multi-Factors Adoption Model (MFAM11) contained eleven (11) factors that have never been systematically integrated into one model.

\section{RESEARCH METHODOLOGY}

This research study performed an extensive literature reviews by consulting articles published on top journals, conference proceedings, also it reviews the books and reports on Information Systems and e-learning systems. The sorting of resources was using the keywords "information systems", "elearning-learning systems". "web-enabled e-learning", "learning management system", "adoption", "virtual learning system" and "course management system".

\section{A. Proposed Model}

The model proposed has eleven (11) constructs as shown in figure 3. A causal approach has been adopted in this study.

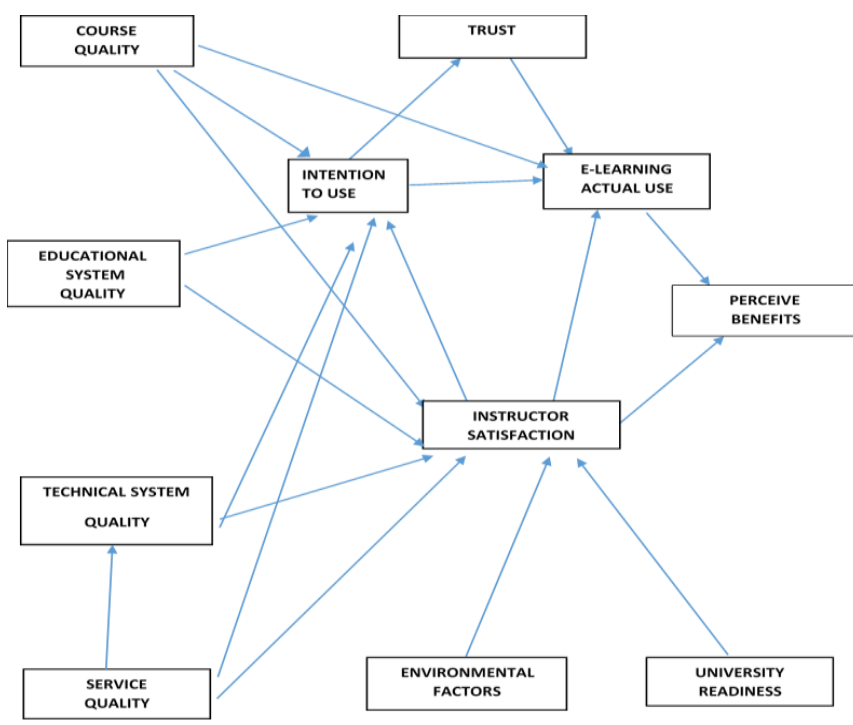

Fig 3. Proposed Multi-Factor Adoption Model. (MFAM11)

Definitions of each construct

\section{A. Course Quality}

This is an information generated by an e-learning system. It is an information related to a course in which an Instructor is in charge. It is a measure of how meaningful the course is [34]. It contains desirable characteristics of the course content as it has been evidenced by the largest number of studies conducted in this category [18], [41].

\section{B. Education System Quality}

This construct measures the quality of education features of e-learning. It includes features for chatting, forum, video and other collaborative features [26]. 


\section{Technical System Quality}

This construct measures the technical attributes of the elearning system. It includes how easy the system is, its interface, security, reliability and availability [34].

\section{Service Quality}

This measure the quality of technical support the IT department provides to the Instructor in the course of using an e-learning system. It includes items like availability, encouragement and training [44].

\section{E. Intention to Use}

The Intention to Use, measure the decision to use an elearning system before you actually use it. It is an attitude. It includes tendency and belief [26].

\section{F. Elearning Actual Use}

This is a construct which measure the extent of which the elearning system (course elements) are actual accessed/used or the amount of effort spend in interacting with the e-learning system [45]. It is a behaviour use of e-Learning system.

\section{G. Instructor Satisfaction}

This is construct measure the expectation of the instructor on the adopted e-learning system. User satisfaction is often regarded as an individual's feelings attained of either be pleased or distress resulting from comparing a product's performance (or outcome) in relation to his or her expectations [26].

\section{H. Environmental Factors}

This is the construct which measure the influence of external environment of the given university on Instructor Satisfaction on e-learning system [46].

\section{University Readiness}

This measure how ready the internal mechanism of a particular university to accommodate the e-learning system [46].

\section{J. Trust}

Trust is the belief that the trustor has on trustee given the systems' environment including vulnerabilities [47]. Here the trustee is e-learning system and trustor is an instructor.

\section{K. Perceived benefits}

This is the impact caused by the adopted e-learning to an individual, group, organizational and community [26]. As time goes on the impacts are out of reach of immediate user so they are about the entire organization or community at large as they perceive, just after adoption of e-learning system [7].

\section{A Brief of Proposed Model}

The proposed model is made up of eleven (11) constructs. Five of them are exogeneous constructs and five of the rest of constructs are intermediate constructs (mediating constructs) and one is the dependent construct. Course Quality, Educational System Quality, Service Quality, Environmental Factors, University Readiness are exogeneous constructs, while Technical System Quality, Intention to Use, E-learning Actual Use, Instructor Satisfaction and Trust are mediating constructs and Perceived Benefits is independent construct. Causal- impacts are used to embrace relationship between the constructs. The overall measurements of e-learning system's adoption are found in Perceived Benefits of system.

\section{CONCLUSIONS}

This study presents the Multi-Factors Adoption Model (MFAM11) which is made up of eleven (11) constructs. The idea of causal-impact is embraced in development of this model. The model came as the ideal solution of the problem of uncomprehensive of developed models and frameworks existing in e-learning systems' adoption in universities in Tanzania which is due to limited number of factors. Hence this research explores the multiple factors and integrate them together in a single model.

This model is subject to validation in a university (ies) domain with instructor perceptions. This proposed model is neither closed model nor universal model; therefore, the researchers have been provided with an opportunity to extend it where necessary to fit it with changes of technologies, users' characteristics and context demands.

\section{REFERENCES}

[1] H. Mohammadi, "Investigating users' perspectives on e-learning: An integration of TAM and IS success model", Computers in Human Behavior, vol. 45, pp.359-374, 2015

[2] J.S. Mtebe and R.Raisamo, "A model for assessing Learning Management System Success in higher education in sub-Saharan countries", The Electronic Journal of Information Systems in Developing Countries, vol.61, no.7, pp.1-17, 2014.

[3] T. Ahmed, "E-learning as a new technological application in higher education and research: An empirical study and proposed model", The International Academic Research Journal, Vol.2, pp.2-13, 2011.

[4] T. Ahmed, "Toward Successful E-learning Implementation in Developing Countries : A proposed Model for Predicting and Enhancing Higher Educations' Participation", International Journal of Academic Research in Business and Social Sciences, Vol.3, no.1, pp.422-425, 2013.

[5] T. Monahan, G. McArdle, and M. Bertolotto, "Virtual reality for collaborative e-learning", Computers \& Education, vol.50, pp.13391353, 2008.

[6] V. Venkatesh, M.G.Morris, G.B. Davis, and F.B. Davis, (2003), "User Acceptance of Information Technology: Toward a Unified View”, "MIS Quartely”, vol.27, no.3, pp.425-478, 2003.

[7] J.B. Raouf, I.S. Naser, and B.K. Jassim, "Determinants of E-Learning Implementation Success in the Iraqi MoHE”, Eng. \&Tech. Journal, vol.30, no.4, pp.659-671, 2012.

[8] Y.S. Wang, H.Y. Wang, and D.Y. Shee "Measuring e-learning systems success in an organizational context: Scale development and validation", Computers in Human Behavior, vol.23, pp.1792-1808, 2007.

[9] M.K. Maina and D.M. Nzuki, D.M, "Adoption Determinants of Elearning Management System in Institutions of Higher Learning in Kenya: A Case of Selected Universities in Nairobi Metropolitan", International Journal of Business and Social Science, pp.233-248, 2015.

[10] K. Yatigammana, M.J.M. Gapar, and C. Gunawardhana, "Postgraduate Students' Perceived E-learning Acceptance: Model Validation", International Journal of Asian Business and Information Management, pp.51-60, 2013.

[11] E. Lwoga and M. Komba, "Antecedents of continued usage intentions of web-based learning management systems in Tanzania" Education+Training, pp.738-756, 2015, [Online], Available: doi:10.1108/ET-02-2014-0014.

[12] W.R. Watson and S.L. Watson, S.L, “An argument for clarity: what are learning management systems, what are they not, and what should they become? TechTrends", Springer Verlag, vol.51, no.2, pp.28-34, 2007 [Online].

Available: https://pdfs.semanticscholar.org/907d/6650d8cea955b7216598e8a592a 8b1b1710c.pdf.

[13] M.Aparicio, F. Bacao, and T. Oliveira, "An e-Learning Theoretical Framework", Educational Technology \& Society, vol.19, no.1, pp.192307, 2016, [Online], Available: 
http://www.ifets.info/journals/19_1/24.pdf.

[14] S. Isaacs and D. Hollow, "The eLearning Africa 2012 Report", Germany: ICWE, 2012. [Online], Available: http://www.elearningafrica.com/pdf/report/ela_report_2012.pdf.

[15] T. Unwin, B. Kleessen, D. Hollow, J. Williams, L.M. Oloo, J. Alwala, I. Mutimucuio, F. Eduardo, and X. Muianga, X, "Digital Learning Mnagement System in Africa: Myths and Realities", The Journal of Open and Distance Learning, vol. 25, no.1, pp.5-23, 2010.

[16] G. Ssekakubo, H. Suleman, and G. Marsden, "Issues of Adoption: Have E-Learning Management Systems Fulfilled their Potential in Developing Countries?", In Proceedings of the South African Institute of Computer Scientists and Information Technologists Conference on Knowledge, Innovation and Leadership in a Diverse Multidisciplinary Environment, pp. 231-238, 2011, Cape Town, South Africa.

[17] D.M. Lashayo and M.J.M. Gapar, "A review of e-learning systems" adoption in Tanzania Universities", South East Asia Journal of Contemporary Business, Economics and Law, vol.13, no. 2, pp.111-118, 2017, [Online], Available: http://seajbel.com/wpcontent/uploads/2017/10/K13-252.pdf

[18] A. Andersson and A. Grönlund, \&, "A Conceptual Framework for ELearning in Developing Countries: A Critical Review Of Research Challenges", The Electronic Journal on Information Systems in Developing Countries, vol.38, no.8, pp.1-16, 2009.

[19] I. Jung, I, "Building a theoretical framework of web - based instruction in the context of distance education", British Journal of Educational Technology, vol.32, no.5, pp.252 - 234, 2001.

[20] T. Anderson, L. Rourke, D.R. Garrison, and W. Archer, "Assessing teaching presence in a computer conferencing context", Journal of Asynchronous Learning Networks, vol. 5, no.2, pp.1-17, 2001

[21] Z.L. Berge, Z. L, "Facilitating computer conferencing: Recommendations from the field", Educational Technology, vol. 35, no.1, pp.22-30, 1995.

[22] I. Dorobă, "Models for Measuring E-Learning Success in Universities: A Literature Review", Informatica Economică, vol.18, no.3, pp.77-89, 2014, [Online], http://dx.doi.org/10.12948/issn14531305/18.3.2014.07.

[23] T. Tossy, T, "Measuring the impacts of e-learning on students' achievement in learning process: an experience from tanzanian public universities", The Online Journal of Distance Education and e-Learning, vol.5, no.2, pp.61-68, 2017, [Online], Available: https://www.tojdel.net/journals/tojdel/articles/v05i02/v05i02-08.pdf

[24] R. Bhalalusesa, E.E. Lukwaro, and M. Clemence, M, "Challenges of Using E-learning Management Systems Faced by the Academic Staff in Distance Based Institutions from Developing Countries: A Case Study of the Open University of Tanzania", Huria Journal of OUT, vol.14, pp.89-110, 2013.

[25] A.Y. AL-Sabawy, "Measuring E-Learning Systems Success (PhD Desseratation)" University of Southern Queensland, 2013, [Online], Available: https://eprints.usq.edu.au/27422/

[26] A. Hassanzadeh, F. Kanaani, and S. Elahi, "A model for measuring elearning systems success in universities", Expert Systems with Applications, vol. 39, pp.10959-10966, 2012.

[27] S.M. Samarasinghe and A. Tretiakov, A, "e-learning system success in an organization context", 2009.

[28] M. Fishbein and I. Ajzen, Belief, Attitude, Intention, and Behavior: An Introduction to Theory and Research, Reading, MA: Addison-Wesley, 1975, [Online], Available: http://people.umass.edu/aizen/f\&a1975.html.

[29] G.L Goodhue and R.L. Thompson, "Task-technology fit and individual performance", MIS Quarterly, vol.19, no.2, pp.213-233, 1995.

[30] F.D. Davis, "Perceived usefulness, perceived ease of use, and user acceptance of information technology", MIS Quarterly, vol.13, no.3, pp.319-340, 1989.
[31] V. Venkatesh and F.D. Davis, "A theoretical extension of the technology acceptance model: Four longitudinal field studies. Management Science", vol.46, no.2, pp.186-204, 2000, [Online], Available: doi: $10.1287 / \mathrm{mnsc} .46 .2 .186 .11926$

[32] L. Tornatzky and M. Fleischer, The process of technology innovation, Lexington, MA, Lexington Books, 1990

[33] E.M. Rogers, Diffusion of innovations, Fourth Edition ed., New York, Free Press, 1995

[34] W. Delone and E.R. McLean, E. R, "The DeLone and McLean Model of Information Systems Success: A Ten-Year Update", Journal of Management Information Systems, vol.19, no.4, pp.9-30, 2003, [Online], Available: doi:10.1.1.88.3031

[35] J.K. Lee and W.K. Lee, W. K, "The relationship of e-Learner's selfregulatory efficacy and perception of e-Learning environmental quality", Computers in Human Behaviour, vol. 24, pp.32-47, 2008.

[36] E.T. Lwoga, "Critical success factors for adoption of web-based learning management systems in Tanzania", International Journal of Education and Development using Information and Communication Technology, vol.10, no.1, pp. 4-21, 2014.

[37] C. Despont-Gros, H. Mueller, H., and C. Lovis, "Evaluating use interactions with clinical information systems: A model based on human-computer interaction models", Journal of Biomedical Informatics, vol. 38, pp.244-255, 2005.

[38] W. DeLone and E. McLean, E, "Information System Success:The Quest for Dependable variable", Information Systems Research, vol.3, no.1, pp.60-95, 1992, [Online], Available: http://home.business.utah.edu/actme/7410/DeLone\%20\&\%20McLean-1992.pdf

[39] H. Lin, H, "Determinants of successful virtual communities: Contributions from system characteristics and social factors", Information \& Management, vol.45, no.8, 2008, pp.522-527, [Online], Available: doi:10.1016/j.im.2008.08.002

[40] C.W. Holsapple and A. Lee-Post, A, "Defining, Assessing, and Promoting E-Learning Success: An Information Systems Perspective", Decision Sciences Journal of Innovative Education, vol.4, no.1, pp.6785, 2006.

[41] A. Lee-Post, "e-Learning Success Model: an Information Systems Perspective", Electronic Journal of e-Learning Volume, vol.7, no.1, pp.61-70, 2009

[42] S. Ozkan and R. Koseler, R, "Multi-dimensional Students' Evaluation of E-learning Systems in the Higher Education Context: An Empirical Investigation", Computers \& Education, vol.53, no.4, pp.1285-1296, 2009.

[43] T. Tossy, "Measuring the impacts of e-learning on students achievement in learning process: an experience from tanzanian public universities", The Online Journal of Distance Education and e-Learning, vol.5, no.2, pp.61-68, 2017, [Online], Available: https://www.tojdel.net/journals/tojdel/articles/v05i02/v05i02-08.pdf

[44] S.M.Samarasinghe and A. Tretiakov, "e-learning system success in an organization context (PhD Desseratation)", University of Massey : Palmerston, New Zealand, 2012, [Online], Available: https://muir.massey.ac.nz/bitstream/handle/10179/4726/02_whole.pdf

[45] Ramayah and Lee, "System Characteristics, Satisfactio and E-learning Usage : A Structural Equation Model (SEM)", The Turkish Online Journal of Educational Technology, vol.11, no.2, pp.196-206, 2012.

[46] G.M. Munguatosha, B.M. Paul, and L. Thaddeus, "A social networked learning adoption model for higher education institutions in developing countries", On the Horizon, vol.19, no.4, pp.307 - 320, 2011.

[47] P.A. Pavlou and M. Fygenson, "Understanding and Predicting Electronic Commerce Adoption : An Extension of the Theory of Planned Behavior", MIS Quarterly, vol.1, pp.115-143, 2011. 